\title{
MENORES Y MEDIOS DE COMUNICACIÓN
}

\author{
Marta Morillas Fernández \\ Profesora Ayudante- Doctora de Derecho Civil \\ Universidad de Granada \\ mmorillas@ugr.es
}

\begin{abstract}
RESUMEN
Actualmente son numerosos los programas de televisión y la información en prensa que se hacen eco de la vida personal e íntima de, en ocasiones, personas anónimas, menores en muchos casos, cuya situación se considera de un interés público relevante, poniendo en riesgo evidente los derechos de su personalidad. Este trabajo intenta dar respuesta a la especial necesidad de protección de los menores de edad ante los medios de comunicación
\end{abstract}

\begin{abstract}
Currently there are numerous television programs and press that use to inform about the personal and intimate life of anonymous persons, minors in many cases, whose situation is considered to be at an important public interest, putting at risk evident rights of his personality. This research work attempts to give an answer to the need of special protection of minors in this area

SUMARIO: I. Introducción.- II. Alcance jurídico de la protección del menor a partir de su capacidad natural: 1 . Intromisión ilegítima del derecho al honor, a la intimidad y a la propia imagen. 2. Derecho a la libertad de expresión en los medios de comunicación y su repercusión con menores.- III. Aplicación Jurisprudencial en la colisión de los derechos implicados cuando se trata de menores: 1. La veracidad de la información. 2. La accesoriedad en el derecho a la imagen del menor. 3. La teoría del reportaje neutral. IV. Consideraciones Finales.
\end{abstract}




\section{INTRODUCCIÓN.}

Los medios de comunicación se muestran en nuestra sociedad como órganos necesarios, destinados a la información pública. Normalmente se hace referencia a los masivos, entendiendo por tales, los destinados a la pluralidad de los ciudadanos. Prensa, televisión y radio se presentan como los más accesibles por los usuarios. Lo derechos que en este ámbito se pueden ver vulnerados son indudablemente el derecho al honor, a la intimidad y a la propia imagen en relación a la persona afectada, y el derecho a la libertad de información y expresión si se trata del medio que lo emite. Cuando estos derechos de la personalidad se refieren a menores de edad se intensifica su regulación y protección. Ciertamente en el Ordenamiento jurídico, existen normas de intensa tutela para ellos en este aspecto al ser sujetos más vulnerables, y en los que probablemente cualquier proyección pública de su vida es posible que incida desfavorablemente en el desarrollo de su personalidad.

No obstante, la realidad diaria nos lleva a reconocer que actualmente son numerosos los programas de televisión y la información en prensa que se hacen eco de la vida personal e íntima de, en ocasiones, personas anónimas, menores en muchos casos, cuya trágica vivencia o situación amorosa se considera de un interés público relevante, lesionando de esta manera los derechos de su personalidad. En otras, menores o hijos de famosos o conocidos por la sociedad, cuya vida o actividades fuera de su profesión recibe el mismo gran interés. Sin olvidar a menores imputados en procedimientos penales, donde en ningún caso podrían identificarse y sin embargo en algunos de gran trascendencia mediática, se ha conocido su imagen así como sus datos personales ${ }^{1}$.

Todo ello origina la existencia de juicios paralelos ocasionando daños verdaderamente considerables hacia los menores. Verdad es, al menos a priori, que no cabe generalizar puesto que existen garantías constitucionales, a veces encontradas,

\footnotetext{
1 Conocido es, sin duda, el caso del Cuco, aunque el artículo 35 de la LO 5/2000, reguladora de la responsabilidad penal de los menores, dispone que "en ningún caso se permitirá que los medios de comunicación social obtengan o difundan imágenes del menor ni datos que permitan su identificación”. En este sentido, ARANGUEZ SANCHEZ, Carlos. "Las declaraciones realizadas en medios de comunicación por menores implicados en procedimientos penales”. En AAVV, Derecho Penal de menores y adolescentes: una visión dual desde Chile y España. Madrid, 2009, pág. 294 y ss. El simple hecho de datos que se transmitan que permitan, la identificación de los menores, relacionándolos como sujetos pasivos de delitos graves, constituye una intromisión ilegítima.
} 
que fundamentan tales derechos fundamentales desde una u otra óptica, lo que puede llevar a una especial colisión entre derechos tales como el de información y los de intimidad, propia imagen e interés del menor, con lo que a veces se precisa de una objetiva y adecuada ponderación que equilibre los intereses informativos y los garantistas de la privacidad del persona y, en este caso, muy especialmente, de los menores, en cada caso concreto.

La industria audiovisual se ha convertido en los últimos años en un sector cada vez con mayor peso y trascendencia para la economía. Los contenidos audiovisuales y su demanda forman parte de la vida cotidiana del ciudadano actual. No se concibe el mundo, el ocio, el trabajo o cualquier otra actividad sin lo audiovisual. La Ley 7/2010, de 31 de Marzo, General de la Comunicación Audiovisual reforma el sector y dota a España de una normativa audiovisual acorde con los tiempos, coherente, dinámica, liberalizadora y con garantías de control democrático, de respeto y refuerzo de los derechos de los ciudadanos, de los prestadores y del interés general. Todas las personas tienen el derecho a que la comunicación audiovisual se realice a través de una pluralidad de medios, tanto públicos, comerciales, privados, comunitarios que reflejen el pluralismo ideológico, político y cultural de la sociedad. El artículo 7, de esta ley, establece que "los menores tienen el derecho a que su imagen y voz no sean utilizadas en los servicios de comunicación audiovisual sin su consentimiento o el de su representante legal, de acuerdo con la normativa vigente. En todo caso, está prohibida la difusión del nombre, la imagen u otros datos que permitan la identificación de los menores en el contexto de hechos delictivos o emisiones que discutan su tutela o filiación”.

La referencia de la citada Ley a la normativa vigente nos lleva a mencionar, en un inicial aproximación, el artículo 20.4 de la Constitución Española, el cual manifiesta que las libertades de expresión e información tienen su límite en el respeto a los derechos reconocidos en el título I, en las leyes que lo desarrollan "y, especialmente, en el derecho al honor, a la intimidad, a la propia imagen y a la protección de la juventud y de la infancia". A su vez, la Ley Orgánica 1/1982, de 5 de mayo , sobre protección del derecho al honor, a la intimidad y a la propia imagen, tras establecer que no se apreciará intromisión ilegítima en el ámbito protegido cuando el titular del derecho hubiere prestado su consentimiento expreso al efecto (artículo 2 ), precisa seguidamente en su 
artículo 3 , en cuanto a los menores de edad (e incapaces) que su consentimiento deberá ser prestado por ellos mismos, si sus condiciones de madurez lo permiten y, de no ser así, el consentimiento habrá de otorgarse mediante escrito por sus representantes legales, quienes estarán obligados a poner en conocimiento previo del Ministerio Fiscal el consentimiento proyectado, habiendo de resolver el Juez si en el plazo de ocho días el Ministerio Fiscal se opusiere.

Las previsiones del artículo 3 de la Ley Orgánica 1/1982 se complementan, en cuanto a los menores, por lo dispuesto en el artículo 4 de la Ley Orgánica 1/1996, de 15 de enero, de protección jurídica del menor, que, entre otros extremos, considera intromisión ilegítima en el derecho al honor, a la intimidad personal y familiar y a la propia imagen del menor "cualquier utilización de su imagen o su nombre en los medios de comunicación que pueda implicar menoscabo de su honra o reputación, o que sea contraria a sus intereses incluso si consta el consentimiento del menor o de sus representantes legales" (artículo 4.3 ). En suma, para que la captación, reproducción o publicación por fotografía de la imagen de un menor de edad en un medio de comunicación no tenga la consideración de intromisión ilegítima en su derecho a la propia imagen (artículo 7.5 de la Ley Orgánica 1/1982 ), será necesario el consentimiento previo y expreso del menor (si tuviere la suficiente edad y madurez para prestarlo), o de sus padres o representantes legales (artículo 3 de la Ley Orgánica 1/1982 ), si bien incluso ese consentimiento será ineficaz para excluir la lesión del derecho a la propia imagen del menor si la utilización de su imagen en los medios de comunicación puede implicar una vulneración en sus derechos ${ }^{2}$.

\section{ALCANCE JURÍDICO DE LA PROTECCIÓN DEL MENOR A PARTIR DE SU CAPACIDAD NATURAL}

Los artículos anteriormente mencionados proyectan el concepto de madurez del menor, que continúa siendo un concepto indeterminado al carecer de una definición

\footnotetext{
${ }^{2}$ Asimismo, no deben dejar de ser tenidas en cuenta las normas internacionales de protección de la infancia (sobre cuyo valor interpretativo ex art. 10.2 CE no es necesario insistir), y, entre ellas, muy en particular, la Convención de las Naciones Unidas sobre los derechos del niño (ratificada por España por Instrumento de 30 de noviembre de 1990), que garantiza el derecho de los niños a la protección de la ley contra las injerencias arbitrarias o ilegales en su vida privada (art. 16 ), así como la Resolución del Parlamento Europeo relativa a la Carta europea de los derechos del niño, en la que se establece que "todo niño tiene derecho a no ser objeto por parte de un tercero de intrusiones injustificadas en su vida privada, en la de su familia, ni a sufrir atentados ilegales a su honor" (apartado 29 del § 8 de la Resolución A 30172/92 de 8 de julio). Vid. STC núm.158/2009 de 29 de junio y SAP de Madrid núm. 256/2011 de 23 de mayo.
} 
legal. Ni en el Código $\mathrm{Civil}^{3}$ ni en otros cuerpos legales se contiene un precepto específico que defina con carácter general cuándo debe considerarse maduro a un menor, aunque si se identifica con la capacidad natural del mismo ${ }^{4}$. Ésta es definida por HOYO SIERRA de manera descriptiva como "un conjunto de aptitudes físicas, psíquicas y sociales que cabe resumir como capacidad de comprensión del alcance de lo que se está realizando y de las consecuencias que de ello se derivan, capacidad de entendimiento y juicio para adoptar decisiones respecto a dichos actos, y como capacidad para comportarse conforme a lo prescrito por el derecho, fundamento esto último de la responsabilidad personal” ${ }^{5}$. Como tal es un concepto de carácter psicológico que incide jurídicamente. En una línea menos psicológica y más social, O’ CALLAGHAN completa la apreciación anterior sobre las condiciones de madurez como "aquellos actos que en el ámbito social se reputan válidos por estar en el ámbito de su capacidad natural, de entender y querer, que varía según la edad y el contenido y la naturaleza del acto concreto que se realiza”6.

Importante resulta en este contexto referirnos a la Resolución de la Dirección General de los Registros y del Notariado de tres de marzo de 1989, que refuerza el criterio anteriormente expuesto y reconoce la capacidad de actuación de los menores en base a la siguiente argumentación: “ En torno a la situación jurídica del menor de edad en nuestro ordenamiento, debe tenerse en cuenta que no existe una norma que, de modo expreso, declare su incapacidad para actuar válidamente en el orden civil, norma respecto de la cual habrían de considerarse como excepcionales todas las hipótesis en

\footnotetext{
${ }^{3}$ En el artículo 162 CC se alude a la madurez como principio básico para el ejercicio de los derechos de la personalidad de los menores, pero no se aporta una definición legal. Art. 162 CC: "Los padres que ostenten la patria potestad tienen la representación legal de sus hijos menores no emancipados. Se exceptúan: 1) Los actos relativos a derechos de la personalidad u otros que el hijo, de acuerdo con las leyes y con sus condiciones de madurez, pueda realizar por sí mismo. 2) Aquellos en que exista conflicto de intereses entre los padres y el hijo. 3) Los relativos a bienes que estén excluidos de la administración de los padres".

${ }^{4}$ Es opinión común la similitud de ambos conceptos entre la doctrina, entre otros, OROZCO PARDO, Guillermo, "Intimidad, privacidad, "extimidad” y protección de datos del menor, pág. 385, y MORILLAS FERNÁNDEZ, Marta, "La protección jurídica del menor ante las redes sociales”, pág .374, ambos en La protección jurídica de la intimidad. Valencia 2010. LÓPEZ SAN LUIS, Rocío, La capacidad contractual del menor, Madrid, 2001, págs. 31-34. GARCIA GARNICA, $\mathrm{M}^{\mathrm{a}}$ del Carmen, El ejercicio de los derechos de la personalidad del menor no emancipado. Especial consideración al consentimiento a los actos médicos y a las intromisiones en el honor, la intimidad y la propia imagen. Navarra, 2004, págs. 196 a 207.

${ }^{5}$ HOYO SIERRA, Isabel Araceli, "La evaluación psicológica de la "capacidad natural” del menor maduro”. En Los menores ante el derecho. Madrid, 2005, pág.59.

${ }^{6}$ O' CALlaghan, Xavier, Compendio de Derecho Civil. Tomo I, $5^{\circ}$ ed., Madrid, 2004, pg.276. En este sentido, Vid., MORENO NAVARRETE, Miguel Ángel-MORILLAS FERNÁNDEZ, Marta, El trastorno mental transitorio en las relaciones de derecho privado. Madrid, 2008, pág. 60 y ss.
} 
que se autorizase a aquel para obrar por sí; y no cabe derivar esa incapacidad ni del artículo $322 \mathrm{CC}^{7}$, en el que se establece el límite de edad a partir del cual se es capaz para todos los actos de la vida civil, ni tampoco de la representación legal que corresponde a los padres o tutores de los hijos menores no emancipados”.

Indudablemente se ha de analizar el artículo 322 en conexión con la técnica del Código Civil de fijar con ocasión de la regulación de actuaciones jurídicas concretas la edad requerida para su válida conclusión lo que permite afirmar que si a partir de los 18 años se presupone el grado de madurez suficiente para toda actuación civil, por debajo de esa edad habrá de atenderse a la actuación concreta que se pretenda realizar, cubriendo la falta de previsión expresa por cualquiera de los medios integradores del ordenamiento legal y no por el recurso a una regla general de incapacidad que además no se aviene ni al respeto hacia la personalidad jurídica del menor de edad ${ }^{8}$.

La relación entre la intimidad, honor e imagen de los menores y la libertad o derecho a la información, por más que haya una abundante doctrina jurisprudencial, no puede tratarse dogmáticamente ni puede fijarse a priori. Es imprescindible contemplar cada caso concreto, a conciencia de que, posiblemente, no existan dos iguales. Sin perjuicio de esto, se impone la necesidad de buscar criterios válidos y coherentes para una aplicación general. En buena línea, CASTILLA BAREA plantea dos que podrían ser comunes a la generalidad de los supuestos: $1^{\circ}$. Aplicar analógicamente las edades especiales inferiores a los dieciocho años que el Código Civil y otras leyes consideran como suficientes para otorgar eficacia jurídica a determinados actos y declaraciones de voluntad de los menores y que suponen una presunción iuris tantum de su capacidad natural; $2^{\circ}$. Atender a la opinión de los padres o representantes legales respecto del grado de madurez del menor para la convicción del juez. Esta premisa sin embargo no

\footnotetext{
${ }^{7}$ Recordad en este sentido, art. 315 CC "La mayor edad empieza a los dieciocho años cumplidos. Para el cómputo de los años de la mayoría de edad se incluirá completo el día del nacimiento”; Art.317 CC "Para que tenga lugar la emancipación por concesión de quienes ejerzan la patria potestad se requiere que el menor tenga dieciséis años cumplidos y que la consienta. Esta emancipación se otorgará por escritura pública o por comparecencia ante el Juez encargado del Registro"; Art.322 CC "El mayor de edad es capaz para todos los actos de la vida civil, salvo las excepciones establecidas en casos especiales por este Código”.

${ }^{8}$ MORILLAS FERNÁNDEZ, Marta. “Régimen de los menores de 14 años”. En El menor como víctima y victimario de la violencia social”. Madrid, 2010, pág. 77.
} 
es generalizable ya que en muchos supuestos el juez reconoce al menor un grado de madurez mayor que el que estiman sus padres ${ }^{9}$.

Por tanto, situándonos en la materia objeto del presente trabajo, no cabe hacer aquí generalizaciones sobre reportajes en que aparecen menores de edad y dar conceptos abstractos sobre si atenta a su intimidad o a su imagen: se debe analizar el caso, ver el contenido, su alcance y comprobar si queda bajo la libertad de información una vez bien delimitado el derecho a la intimidad y verificar el consentimiento del menor y de sus representantes legales. Teniendo en cuenta, eso sí, desde nuestro criterio, la capacidad que según su edad el Ordenamiento jurídico le otorga para la celebración de determinados actos jurídicos y que consecuentemente le harán tener el grado de madurez exigible según la ley para prestar su consentimiento en el ámbito que estamos tratando ${ }^{10}$.

Para ello hemos de destacar, en principio, dos hipótesis sobre lo comentado, que verifican la importancia del consentimiento bien para aceptarlo o bien para rechazarlo.

En la primera de ellas, el Tribunal Supremo, en su sentencia número 287/2003 de 26 de marzo, presume una capacidad normal, mientras no se acredite una incapacidad, a la situación del joven de 14 años, con una vida como el mismo relata desgraciada y agitada, lo cual no permite negar unas claras condiciones de madurez para consentir una entrevista por televisión, en la que narra la agresión sufrida por otros jóvenes que le golpearon y asestaron varios navajazos. De manera que desestima la

\footnotetext{
${ }^{9}$ CASTILlA BAREA, Margarita. Las Intromisiones Legítimas en el Derecho a la Propia Imagen. Cuadernos de Aranzadi Civil. Pamplona, 2011, págs. 135 y ss.

${ }^{10}$ Un análisis de las normas relativas a la capacidad de los menores para realizar actos jurídicos revela que al menos hay tres momentos determinantes previos a alcanzar con carácter general la mayoría de edad: serían los doce, catorce y dieciséis años: a) A partir de los doce se exige el consentimiento del menor para constituir su adopción, deberán ser oídos por el juez sobre el ejercicio de la patria potestad, en caso de conflicto con sus progenitores (artículo 92 y 156 CC), para la constitución de la tutela (artículo 231 CC), para aquellos actos en que el tutor necesite autorización judicial (artículo 273 CC).b) A partir de los catorce el menor puede cambiar de estado civil con la asistencia de su representante legal (vecindad civil-artículo 14.3, pár.4º nacionalidad-artículos.20.2b) y 21.3.b)-), contraer matrimonio con dispensa judicial, ejercer la patria potestad sobre sus hijos, tener responsabilidad penal por sus actos, poder realizar testamento, salvo el ológrafo.-c) Y a partir de los dieciséis años el menor puede trabajar, realizar la administración ordinaria de los bienes que ha obtenido con su trabajo o industria, consentir la enajenación o gravamen de sus bienes en los términos a los que se refiere el art 166, pár. $3^{\circ}$. CC, ceder los derechos de explotación sobre su propiedad intelectual y para el caso de las mujeres, Ley Orgánica de Salud Sexual y Reproductiva y de la Interrupción Voluntaria del Embarazo, por remisión a la Ley 41/2002 básica reguladora de la autonomía del paciente y derechos y obligaciones en materia de información y documentación clínica, según la cual se podrá interrumpir voluntariamente el embarazo con su consentimiento.
} 
demanda interpuesta por el Ministerio Fiscal, en defensa del menor contra la cadena de televisión.

Y en la segunda, más alejada de nuestro orden jurisdiccional pero coincidente en nuestro planteamiento jurídico del consentimiento otorgado por menores, se encuentra la sentencia número 3292/2012 de 3 de abril de la Sala de lo Penal del Tribunal Supremo. Trata el caso de una menor, que presta su consentimiento para la grabación de un video pornográfico. En este caso el consentimiento es no válido, en el sentido de que no concurren condiciones de libertad para el ejercicio de la sexualidad por parte de ella, cuando dicho ejercicio implica su utilización por terceras personas con fines pornográficos o exhibicionistas, lo que implica que un sector doctrinal considera, en cuanto a cual sea el bien jurídico protegido, que no es tanto la indemnidad sexual de la personalidad del menor, como su dignidad como menor o su derecho a la propia imagen, lo que justifica esa irrelevancia del consentimiento de los menores de 18 años que deciden intervenir en la elaboración del material pornográfico, incluso sin mediar abuso de superioridad o engaño. Cuando ese consentimiento, por el contrario, si sería válido para la práctica de relaciones sexuales cuando no mediasen tales circunstancias. Se trata de preservar y proteger a los menores.

El bienestar psíquico de estas personas requiere una adecuada protección por cauce de madurez necesaria para decidir con responsabilidad sobre este tipo de comportamientos que pueden llegar a condicionar gravemente el resto de una vida, por lo cual es indiferente a efectos jurídicos penales que el menor o incapaz consientan en ser utilizados para este tipo de conductas.

Indudablemente al tratarse de menores que se encuentran en un período transcendental en su personalidad, podría verse ésta afectada por actuaciones que puedan condicionar de un modo negativo la vida de futuro de aquéllos $\mathrm{y}$, de alguna manera, limitada su propia dignidad, por lo que es irrelevante el consentimiento de los mismos en determinadas actuaciones, no ya penales, sino también aquellas que vulneren su derecho a la intimidad personal o familiar, al honor y a la propia imagen.

\section{Intromisión ilegítima del Derecho al Honor, a la Intimidad y a la Propia Imagen.}


Por lo que respecta a los derechos que pueden ser vulnerados cuando se trata de menores y medios de comunicación conviene destacar brevemente, que el derecho al honor está integrado por dos aspectos: por un lado el de la inmanencia, consistente en la estimación que cada persona hace de sí misma, y por otro el de la trascendencia o exterioridad, compuesta por el reconocimiento que los demás hacen de nuestra dignidad, es decir, que el ataque al honor se desenvuelve tanto en el marco personal como social $^{11}$.

En segundo lugar, es ya doctrina reiterada y asentada, que la imagen es la representación gráfica de la figura humana, visible y reconocible, y el derecho a la imagen es un derecho de la personalidad, derivado de la dignidad humana y dirigido a proteger la dimensión moral de las personas que atribuye a su titular un derecho a determinar la información gráfica generada por sus rasgos físicos personales que puede tener difusión pública. Tiene un aspecto negativo, como facultad de exclusión, y un aspecto positivo, como facultad de aprovechamiento; es, por tanto, una facultad del interesado de difundir o publicar su propia imagen y, por ende, su derecho a evitar su reproducción ${ }^{12}$.

Y en tercer lugar, al derecho a la intimidad se califica como el poder concedido a la persona sobre el conjunto de actividades que forman su círculo íntimo, personal y familiar, que le permite excluir a los extraños de entrometerse en él y de darle una publicidad que no desee el interesado. Estamos ante un derecho de la personalidad, como expresa el artículo 18.1 de la Constitución, derecho independiente, autónomo, separado del derecho al honor y del derecho a la imagen y que, a su vez, comprende dos aspectos, la intimidad personal y la intimidad familiar, y predomina el aspecto negativo, esto es de exclusión ${ }^{13}$.

Lo que el artículo 18.1 CE garantiza, como indica el Tribunal Constitucional, es un derecho al secreto, a ser desconocido, a que los demás no sepan qué somos o lo que hacemos, vedando que terceros, sean particulares o poderes públicos, decidan cuáles son

\footnotetext{
${ }^{11}$ Así se pronuncia el Tribunal Supremo en sentencias de 23 de marzo de 2003, 23 de febrero, 24 de abril y 12 de mayo de 1989 , y 11 de junio de 1990.

${ }^{12}$ Entre otras muchas, STC 83/2002 de 22 de abril. Para un concepto más amplio, Vid. DE LAMA AYMÁ, Alejandra. La protección de los derechos de la personalidad del menor de edad. Valencia, 2006, pág. 109 y ss.

${ }^{13}$ SSTS 602/2011 de 29 de julio y 6239/2011 de 6 de septiembre.
} 
los límites de nuestra vida privada pudiendo cada persona reservarse un espacio resguardado de la curiosidad ajena, sea cual sea lo contenido en ese espacio. Del precepto constitucional se deduce que el derecho a la intimidad garantiza al individuo un poder jurídico sobre la información relativa a su persona o a la de su familia, pudiendo imponer a terceros su voluntad de no dar a conocer dicha información o prohibiendo su difusión no consentida lo que ha de encontrar sus límites, como es obvio, en los restantes derechos fundamentales y bienes jurídicos constitucionalmente protegidos. A nadie se le puede exigir que soporte pasivamente la revelación de datos, reales o supuestos, de su vida privada personal o familiar ${ }^{14}$.

El artículo 7 de la ya citada Ley Orgánica 1/1982 de 5 de mayo, de Protección Civil del Derecho al Honor, a la Intimidad y a la Propia Imagen, recoge qué ha de entenderse por intromisión ilegítima, indicando que existirá en la instalación de dispositivos que permitan la captación de imágenes y/o sonido relativos a la intimidad de las personas, su utilización, la difusión de datos sobre la vida privada de una persona o familia que afecten a su reputación y buen nombre, la divulgación de datos privados obtenidos en el ejercicio de la profesión de quien los revela, la captación, reproducción o publicación por fotografía, filme, o cualquier otro procedimiento, de la imagen de una persona en lugares o momentos de su vida privada o fuera de ellos (con las salvedades establecidas en la propia ley), así como la imputación de hechos o la manifestación de juicios de valor a través de acciones o expresiones que de cualquier modo lesionen la dignidad de otra persona, menoscabando su fama o atentando contra su propia estimación.

El Tribunal Constitucional ha venido señalando que, para que el derecho a la intimidad pueda oponerse legítimamente como un límite al derecho a la libertad de recibir o transmitir información, es preciso que las noticias difundidas carezcan de interés público o que, aun siendo de interés público, carezcan de veracidad, ya que en una sociedad democrática que proclama como uno de los principios que inspiran su convivencia el respeto a la dignidad de la persona, no debe tolerarse la divulgación de hechos que pertenecen a la intimidad de ciudadanos particulares, ni tampoco se debe tolerar que las noticias que se difundan no sean veraces, no en el sentido de que las mismas coincidan exactamente con las acontecidas, sino en el sentido de que se haya

\footnotetext{
${ }^{14}$ STC $134 / 1999$ de 15 de julio.
} 
desplegado por quien las publica la diligencia necesaria para cerciorarse de que lo que se divulga no es un simple rumor ${ }^{15}$.

Sin embargo, en los supuestos en los que están implicados menores de edad, la doctrina constitucional ha otorgado un ámbito de superprotección que obliga a ser sumamente cautelosos en cuanto a la información que de los mismos se suministra, aunque ésta tenga interés público. Y, así, el Tribunal Constitucional ha señalado que el legítimo interés de un menor de que no se divulguen datos relativos a su vida familiar o personal parece imponer un límite infranqueable tanto a la libertad de expresión como al derecho fundamental a comunicar libremente información veraz, sin que la supuesta veracidad de lo revelado exonere al medio de comunicación de responsabilidad por la intromisión en la vida privada de los menores ${ }^{16}$.

\section{Derecho a la libertad de expresión en los medios de comunicación y su repercusión con menores}

El artículo 20.1.a) y d) de la Constitución Española, en relación con el 53.2 del mismo texto legal, reconoce como derecho fundamental especialmente protegido mediante los recursos de amparo constitucional y judicial el derecho a expresar y difundir libremente los pensamientos, ideas y opiniones mediante la palabra, el escrito o cualquier otro medio de reproducción y el derecho a comunicar o recibir libremente información veraz por cualquier medio de difusión ${ }^{17}$.

La libertad de información comprende la comunicación de hechos susceptibles de contraste con datos objetivos y tiene como titulares a los miembros de la colectividad y a los profesionales del periodismo. La libertad de expresión tiene un campo de acción más amplio que la de información ya que mientras ésta última se refiere a la narración

\footnotetext{
${ }^{15}$ SSTC números 54/2004, de 15 de abril y 61/2004, de 19 de abril.

${ }^{16}$ STC número 134/1999 de 15 de julio. PAÑOS PEREZ, Alba. "El interés del menor como criterio para determinar la ilegitimidad de la intromisión en los derechos del honor, la intimidad y la propia imagen del menor”. En Actualidad Civil, No8, Quincena del 16 al 30 de abril de 2012, Tomo 1. LA LEY, pág. 23 y ss.

${ }^{17}$ STS número 201/2012 de 26 de marzo.
} 
de hechos, la de expresión alude a la emisión de juicios, creencias, pensamientos y opiniones personales y subjetivas ${ }^{18}$.

El derecho al honor y a la intimidad personal y familiar se encuentra limitado por las libertades de expresión y de información. Esto se produce cuando existe un conflicto entre tales derechos que ha de ser resuelto mediante técnicas de ponderación, aplicables a cada caso concreto ${ }^{19}$. Se entiende por ponderación, una vez que existe la colisión de derechos, el examen de la intensidad y trascendencia con la que cada uno de ellos resulta afectado, con el fin de elaborar unos parámetros que permitan, dando preferencia a unos u otros, la resolución del caso mediante la prevalencia entre ellos.

El Tribunal Constitucional ha dicho, al respecto, que en relación con los hechos de la vida social el elemento decisivo para la información no puede ser otro que la trascendencia pública del hecho del que se informa por razón de la relevancia pública de la persona o del propio hecho en el que ésta se ve involucrada, y que es tal hecho, el que la convierte en noticia de interés general con la consecuencia de que en tal caso, el ejercicio del derecho a comunicar libremente información gozará de un carácter preferente sobre otros derechos como el derecho al honor. En caso contrario, el derecho a la información se convertirá en cobertura formal para atentar sin límite y con abuso del derecho en el honor y la intimidad de las personas con afirmaciones o consideraciones que carecen de valor alguno con el interés general del asunto en concreto. Todo esto significa, en consecuencia, que cuando el sujeto pasivo tiene una proyección pública, política, social o económica, su protección al derecho al honor se disminuye, su derecho a la intimidad se diluye y su derecho a la imagen se excluye, dado que las mismas, por su relevancia pública, están obligadas a soportar un cierto riesgo de que sus derechos subjetivos de la personalidad resulten afectados por opiniones o informaciones, debilitándose su derecho al honor y a la intimidad proporcionalmente como límite extremo de la libertad de expresión e información ${ }^{20}$.

De este modo quien de cualquier forma hace una exposición personal a los demás de su modo de vida, participando a través de cualquier medio, y acepta instalarse

\footnotetext{
${ }^{18}$ SSTC números 29/2009 de 26 de enero y 77/2009 de 23 de marzo.

${ }^{19}$ SSTS números 2666/2012 de 24 de abril y 2634/2012 19 de abril.

${ }^{20}$ Doctrina jurisprudencial aplicada por la STS 6239/2011 de 6 de septiembre.
} 
en el mundo de la fama no sólo contribuye a delimitar el terreno reservado a su intimidad sino que se está sometiendo a la opinión de la sociedad. El menor, en este sentido, tiene una protección reforzada que se intensifica cuando el daño provocado mediante el ataque a sus derechos se realiza a través de los medios de comunicación.

Esta doctrina se aplica, entre otras, en la STS de 6 de septiembre de 2011, sobre protección del derecho a la imagen y a la intimidad, por la publicación en una revista de unas imágenes de la demandante, conocida por su profesión y por su relación sentimental, haciendo top less en una playa. El principal objeto de la controversia radica en que, según alega, era menor de edad cuando se captaron estas imágenes. La técnica de la ponderación anteriormente mencionada y practicada en este asunto permite valorar los hechos y derechos en colisión. Desde esta perspectiva y como fruto de lo comentado hasta ahora, indica el Tribunal Supremo que la técnica de la ponderación exige que ${ }^{21}$ : a) la información tenga relevancia pública o interés general en cuanto puede contribuir al debate en una sociedad democrática cuando se proyecta sobre personas que desempeñan un cargo público o tienen una personalidad política y ejercen funciones oficiales o se trata, simplemente, de satisfacer la curiosidad humana por conocer la vida de personas con notoriedad pública que no ejerzan tales funciones; b) la libertad de información, para que pueda prevalecer sobre el derecho al honor, exige que la información cumpla el requisito de la veracidad; c) la prevalencia del derecho a la información sobre el derecho a la imagen sea mayor que sobre el derecho a la intimidad, por cuanto en relación con la vida privada de las personas debe tenerse en cuenta el principio de proporcionalidad con el interés público en los aspectos de esta que se difunden y la forma en que tiene lugar la difusión; d) la ponderación entre los derechos en conflicto debe efectuarse teniendo en cuenta si la publicación de los datos de la vida privada está justificada por los usos sociales, o hay base para sostener que el afectado adoptó pautas de comportamiento en relación con su ámbito íntimo que permita entender que, con sus propios actos, lo despojó total o parcialmente del carácter privado o doméstico; e) en los casos en los que los intereses de los menores están afectados, la normativa tanto interna como internacional otorgan una especial protección al interés del menor ${ }^{22}$.

\footnotetext{
${ }^{21}$ Vid las sentencias más recientes del Tribunal Supremo sobre los criterios de ponderación en la colisión de estos derechos, SSTS 3118/2012 7 de mayo, 3055/2012 7 de mayo, 2666/2012 de 24 de abril, 2631/2012 de 19 de abril, 2634/2012 de 19 de abril, 2753/ 2012 de 18 de abril.

22 El artículo 4.3 de la LO 1/1996, de 15 de enero , de Protección Jurídica del Menor, establece que constituye intromisión ilegítima la utilización de imágenes de los menores en los medios de comunicación
} 
La aplicación de dicha doctrina en el caso anteriormente mencionado, determina el diferente tratamiento jurídico que en la misma situación se le daría a un mayor de edad. Efectivamente, en el caso enjuiciado, se produce una colisión entre la libertad de información y el derecho a la propia imagen de la actora, que era menor de edad en el momento de captación y divulgación, sin su consentimiento, de imágenes en top-less en una playa.

Delimitados los derechos, desde un punto de vista abstracto, ha de considerarse como punto de partida la posición prevalente que, como se ha expresado, ostenta el derecho a la libre información en su máxima expresión, por ejercitarse por profesionales de la información en el cauce institucionalizado de los medios de comunicación. Esta posición, que en casos de fotografías tomadas a mayores de edad, llevaría al examen de las circunstancias concretas del caso para examinar si se sigue manteniendo frente al derecho a la propia imagen del afectado, no puede mantenerse, sin embargo, en este caso al tratarse de un menor de edad cuando fueron captadas las fotografías, en atención a los hechos probados de la sentencia recurrida. En tal sentido, indiscutiblemente, prima el interés del menor, interés que se superpone al derecho a la información, sin que el examen de los requisitos que permitirían un ejercicio legítimo del derecho a la información (interés informativo, veracidad y proporcionalidad) sea razón suficiente para franquear el límite que el interés del menor impone en este tipo de casos. No son pues, datos que deban ser valorados ni la proyección pública de la demandante, ni el interés informativo suscitado por su persona o por los hechos, ni el carácter público del

que sea contraria a sus intereses, como la internacional (artículo 24 del Pacto Internacional de Derechos Civiles y Políticos de 19 de diciembre de 1.966 ; artículo 6 del Convenio Europeo hecho en Roma el 4 de noviembre de 1.950 para la Protección de los Derechos Humanos y de las Libertades Fundamentales; artículo 8 de las Reglas mínimas de las Naciones Unidas para la administración de justicia de menores de 29 de noviembre de 1.985 -Reglas de Beijing-; y artículo 3 y 40 de la Convención sobre los Derechos del Niño, adoptada por las Naciones Unidas en 20 de noviembre de 1.989 ) La Carta Europea de derechos del niño de 21 de septiembre de 1992 reconoce que todo niño tiene derecho a ser protegido contra la utilización de su imagen de forma lesiva para su dignidad. Esta especial protección legislativa ha sido reconocida en la jurisprudencia constitucional y de esta Sala. Así, la STC 158/2009 de 29 de junio establece que en « la captación y difusión de fotografías de niños en medios de comunicación social, es preciso tener en cuenta, que el ordenamiento jurídico establece en estos supuestos una protección especial, en aras a proteger el interés superior del menor . También ha señalado que « ni existe un interés público en la captación o difusión de la fotografía que pueda considerarse constitucionalmente prevalente al interés superior de preservar la captación o difusión de las imágenes de los menores en los medios de comunicación, ni la veracidad de la información puede justificar esa intromisión ilegítima en el derecho a la propia imagen de los menores, pues este derecho fundamental del menor «viene a erigirse, por mor de lo dispuesto en el art. 20.4 CE , en límite infranqueable al ejercicio del derecho a ponderación en el caso concreto $>>$. 
lugar en el que se tomaron las fotografías puesto que la intromisión ilegítima en la imagen se produce en virtud del artículo 4 de la LOPJM. La definición legal, por otro lado, relativa a la utilización de la imagen aclara la controversia que pudiera suscitarse en torno a la publicación, siendo mayores de edad, de imágenes de menores de edad como ocurre en este caso, pues lo que se considera ilegítimo es la utilización de imágenes en las que se encuentre un menor, con independencia del momento en que se publique, circunstancia en la que habrá de analizarse el resto de los requisitos exigidos por la norma (menoscabo de su honra o contrario a sus intereses).

En este caso, no ha sido objeto de controversia el resto de los requisitos, pero es incuestionable que la imagen de una menor desnuda o semidesnuda obtenida sin su consentimiento, no solo supone un menoscabo para el menor sino también contraria a sus intereses.

\section{APLICACIÓN JURISPRUDENCIAL EN LA COLISIÓN DE LOS DERECHOS IMPLICADOS CUANDO SE TRATA DE MENORES.}

\section{La veracidad de la información.}

Se ha especificado anteriormente que la aplicación de los criterios de ponderación, conducen a determinar a priori si la información emitida tiene relevancia pública o interés general, y para que la misma pueda prevalecer sobre el derecho al honor, se exige que la información cumpla con la premisa de veracidad, entendiéndola como el resultado de una razonable diligencia por parte del informador para contrastar la noticia de acuerdo con pautas profesionales. Este requisito resulta de menor trascendencia cuando se afecta al derecho a la intimidad personal y a la propia imagen. En relación al primero de ellos la verdad de lo divulgado es presupuesto necesario para la vulneración del derecho, mientras que en el segundo realmente la imagen que se proyecta no debe plantear, en principio, ningún problema de veracidad ya que a no ser que se truque la imagen o el texto informativo no se corresponda con el momento de captación de la 
misma, la persona captada gráficamente será coincidente con el objeto de la información.

Cuando se trata de menores de edad, se intensifica la protección, de tal manera que no puede existir un interés público en la captación o difusión de las fotografías que pueda considerarse constitucionalmente prevalente al interés superior de preservar la captación o difusión de las imágenes de los menores en los medios de comunicación. Ni la veracidad de la información puede justificar esa intromisión ilegítima en el derecho a la propia imagen de los menores, pues este derecho fundamental del menor, es límite infranqueable al ejercicio del derecho a ponderación en el caso concreto.

Esta doctrina sobre veracidad de la información y su repercusión con menores, queda fijada entre otras muchas, en la STS 5814/ 2011 de 29 de julio, sobre el caso de una famosa que actúa en su nombre y en el de su hija menor de edad, demandando a una cadena de televisión y a la persona que efectuó comentarios insidiosos y falsos imputándole conductas constitutivas de delito en el proceso de adopción de su hija así como la revelación de datos relativos al origen y familia biológica, lo cual supone una intromisión ilegitima en los derechos fundamentales de la menor ${ }^{23}$.

Las cuestiones que aquí, en la sentencia, se plantean son dos. En primer lugar, la relevancia pública e interés general al ser una persona con notable proyección pública por su actividad artística y que puede trasmitir a los telespectadores un trato de favor en el expediente de adopción internacional de su hija; materia ésta que sí presenta un

\footnotetext{
${ }^{23}$ Es importante resaltar que en este caso, a priori los derechos de la menor quedan vulnerados. Sin embargo el Juzgado de Primera Instancia desestimó la demanda, entre otras causas porque la demandante es un personaje público, la información tiene relevancia pública y social y no atenta contra la intimidad, su derecho al honor ha de ser disminuido por ser un personaje público, y porque lo que la demandada contó se corresponde con la denuncia y la investigación en la que queda constancia de que el proceso estuvo lleno de irregularidades e ilícitos que han prescrito con el tiempo. La Audiencia Provincial estima parcialmente un recurso de apelación en base a: a) que es antijurídica una información relativa a los detalles de una adopción y de sus protagonistas porque no posee relevancia pública al no servir al interés general en la información y porque no se refiere a un asunto público; b) los hechos que relata la demandada no resisten crítica, afirma que se pagaron grandes cantidades para la adopción de su hija pero no se acreditan mínimamente, y la Fiscalía del país de origen de la menor por contradictorias no le da valor alguno al carecer de garantías las afirmaciones de la demandada en orden a la salida del país, la reducción del periodo de empatía y las posibles irregularidades en el expediente de adopción; c) en las conclusiones de la Fiscalía de Perú se declara que no hay rastro de delito, ni de intento de colaboración con una red de tráfico ilegal de menores, ni delito de sustracción de menores, ni explotación de los mismos; d) no se encuentra causa de justificación para exponer públicamente los problemas de adopción ocurridos 10 años antes sin indicar la dudosa fiabilidad de la entrevistada que había pasado de ser policía a estar acusada por estafa y ser de dudosa la legalidad de su estancia en España, al tener prohibida la salida de su país.
} 
evidente interés social ya que el proceso debe ir presidido por la igualdad de los solicitantes y el cumplimiento escrupuloso de los requisitos fijados, respetando los principios de objetividad y transparencia. En segundo, la posición jurídica de la menor en toda esta vorágine cuya causa principal es el intento de justificación en la vulneración de sus derechos por el hecho de que su madre sea famosa. El carácter público no se posee por ser hija de una persona conocida y, por tanto, carece por sí misma de notoriedad y la difusión de sus datos no contribuye en nada a la formación de la opinión pública.

Indica la susodicha sentencia que la doctrina constitucional ha declarado reiteradamente que el requisito de veracidad no coincide con el de la verdad objetiva de lo publicado o difundido, ya que cuando la Constitución requiere que la información sea veraz no está tanto privando de protección a las informaciones que puedan resultar erróneas como estableciendo un deber de diligencia sobre el informador a quien se puede y debe exigir que lo que transmite como hechos, hayan sido objeto de previo contraste con datos objetivos. El requisito de la veracidad deberá entenderse, como advierte el Tribunal, cumplido en aquellos casos en los que el informador haya realizado, con carácter previo a la difusión de la noticia, una labor de averiguación de los hechos sobre los que versa la información y la referida indagación la haya efectuado con la diligencia exigible a un profesional de la información, debiendo rechazarse la transmisión de rumores, invenciones o insinuaciones insidiosas, así como la de noticias gratuitas o infundadas.

En el presente caso de la prueba practicada se extrae que no se ha empleado como fuente directa de la información unas diligencias policiales y judiciales abiertas en las que se confirmaría su contenido y que implicaría que los datos transmitidos en ese momento por el informante no pudieran calificarse de producto de la mera invención o carentes de fundamento fáctico, sino que queda constancia de una falta de diligencia cuando la información es obtenida por medio de una persona que había trabajado con anterioridad con la demandante que no aporta datos fácticos objetivos que permitan sustentar sus declaraciones y que no se utilizó la posibilidad de acudir a organismos oficiales a efectos de contrastarla. En atención a todo lo expuesto, como manifiesta el Ministerio Fiscal, en el supuesto que nos ocupa, el informador no acredita haber realizado, con carácter previo a la difusión de la noticia, una labor de averiguación del hecho concreto relativo a la actividad de la demandante con el nivel de diligencia 
exigible a un profesional de la información. El requisito de veracidad aparece referido al grado de diligencia observado para la comprobación de unos hechos con anterioridad a la emisión de aquellos y no con que a posteriori se pruebe la realidad de los hechos y en ese sentido, la diligencia exigible para invocar el ejercicio de la libertad de información frente al contenido vejatorio. Se dan a conocer detalles y datos relativos al proceso de adopción y al origen e identidad biológica de la menor que invaden gratuitamente la intimidad sin causa justa, y que debe considerarse como ilegítimos al ofrecerse datos identitarios que objetivamente forman parte de la intimidad de la persona afectada y estaba encaminada a divulgarlos. Asimismo inciden en el derecho a la intimidad del menor por cuanto se da a conocer públicamente una serie de circunstancias personales y familiares que en nada interesan al público en general y que pudieran afectar al normal desarrollo de su personalidad al poner en público conocimiento circunstancias de su procedencia familiar.

Desde este punto de vista, en conclusión del Tribunal Supremo, y como aplicación de la doctrina al caso enjuiciado, la afectación del derecho a la intimidad personal y familiar es muy elevada frente a la protección del derecho a la libertad de información y expresión. La consideración de las circunstancias concurrentes conduce a estimar que la libertad de información y expresión no puede en este caso prevalecer sobre el derecho al honor y a la intimidad personal, pues el grado de afectación de la primera es muy débil y el grado de afectación de los segundos es de gran intensidad.

\section{La accesoriedad en el derecho a la imagen del menor.}

Indudablemente cuando se produce una vulneración del derecho al honor, a la intimidad y a la propia imagen de un menor, la máxima defensa del medio de comunicación demandado radica en la defensa de la accesoriedad de la imagen dentro del contexto principal de la noticia. La regulación jurídica, en este sentido, se encuentra en el artículo 8.2 c) de la LO 1/1982, el cual manifiesta que el derecho a la propia imagen no impedirá la información gráfica sobre un suceso o acaecimiento público, cuando ésta aparezca como meramente accesoria. Ante esto debemos entender que si los menores aparecen gráficamente reconocidos en una noticia de carácter general, en un lugar abierto al público, no atentará esto contra su derecho a la intimidad o a la propia imagen. 
La imagen accesoria se conceptualiza como aquella que se encuentra dentro de un reportaje gráfico de manera secundaria e intrascendente y nunca como principal de tal manera que en la noticia, el menor no podría ser el eje principal de la misma. Ha de partirse de que tanto los menores como los medios de comunicación forman parte de la sociedad y de la vida ordinaria y de que la especial tutela del honor, intimidad e imagen de los menores no implica la expulsión de éstos de los medios. Incluso deben admitirse supuestos para los que no sean necesarios ni consentimientos ni autorizaciones, cuando la afectación a los derechos sea irrelevante si, de acuerdo con los usos sociales, la emisión de la imagen o ciertos datos del menor puede considerarse totalmente inocua para sus intereses ${ }^{24}$.

En este sentido, el artículo 7.5 de la LO 1/1982 contempla la posibilidad de que no exista intromisión ilegítima en fotografías de la imagen de una persona famosa, en su vida pública o privada, en lugares abiertos y cuando otra aparezca como accesoria.

Este planteamiento aplicado a los menores, hijos de esas personas populares o con notoriedad pública, no puede ser trasladado automáticamente a ellos, ya que han de tener la misma protección en su vida personal que los hijos de padres no conocidos socialmente. Así lo destaca la Instrucción de la Fiscalía General del Estado número 2/2006, de 15 de marzo, al indicar que tienen el mismo grado de protección que cualquier menor, frente a la curiosidad ajena, y la captación y reproducción de la imagen de los progenitores con sus hijos en lugares públicos, no excluye la ilicitud de la intromisión en el derecho a la imagen de los menores. Los menores hijos de personajes famosos son, sin más, menores, y como tales con derecho al mismo grado de protección

\footnotetext{
${ }^{24}$ La Instrucción de la Fiscalía General del Estado número 2/2006, de 15 de marzo, destaca que en este sentido puede considerarse ilustrativa la SAP Valencia, ${ }^{\circ}$ 86/2002, de 13 de febrero, que declara que "la utilización de la imagen de la menor, captada en la vía pública en un acto de alta participación popular, no atenta contra su derecho a la imagen, no sólo porque el fotometraje es respetuoso con la menor, pues aparece vestida de fallera en el acto de la ofrenda, sino, también, porque dicha imagen es captada en un acto de masiva participación popular, resaltando el carácter accesorio, pues aparece tan sólo unos segundos, introduciendo el apartado dedicado la ofrenda, al igual que el resto de los apartados son introducidos por un fotomontaje alegórico de su contenido... el caso que se enjuicia no participa de los mínimos requisitos para el reconocimiento de la vulneración del derecho ya que la imagen de la menor fue captada en la vía pública al participar en los actos falleros, no constituyendo el objeto principal de la divulgación de imágenes, pág.33.
} 
frente a la curiosidad ajena, sean cuales sean las actividades a que se dediquen sus progenitores o la dejación que éstos hayan hecho de sus derechos.

Por lo que siguiendo con la citada Instrucción, los casos de personajes públicos que explotan el relato de sus intimidades, incluyendo en éstos las de sus hijos, habrán de ser tratados por el Fiscal, de acuerdo con el principio del superior interés del menor y de su legitimación autónoma, de modo y manera que, ponderando las circunstancias concurrentes, procederán en su caso a entablar la correspondiente demanda en interés del menor y contra sus progenitores y el medio.

Resulta, en este sentido, cuanto menos imprescindible referirnos a dos casos en la jurisprudencia menor, enjuiciados por la Audiencia Provincial de Madrid ${ }^{25}$, en los que se trata la importancia del carácter principal o accesorio de las imágenes captadas. Supuestos en los que tanto el padre como la madre son personajes conocidos. La primera de ellas se refiere a la publicación de fotografías en diferentes fechas del demandante con sus hijos en competiciones hípicas, en la playa o de viaje. No se presta en ningún caso el consentimiento por parte del progenitor y los menores son protagonistas de la noticia. La imagen de los menores no aparece de manera accesoria en el reportaje, como defiende el medio de comunicación, sino con carácter principal, esto es, con el mismo protagonismo, al menos, que el padre o la madre, y no como terceros ajenos a los hechos del reportaje. Al ser la representación gráfica de la figura de un menor, es mucho más restringida la consideración de la accesoriedad, por la especial protección que le brinda la mencionada Ley Orgánica 1/1996, de 15 de enero de protección jurídica del menor. No existe distorsión bastante de la fisonomía del rostro de los menores en las imágenes publicadas y son perfectamente reconocibles.

En relación al segundo de los casos anteriormente mencionados, la actora madre conocida de los dos menores, ejercita acción de protección jurisdiccional por intromisión ilegítima en la intimidad y propia imagen de los mismos, como consecuencia de la publicación en una revista del corazón de sendas fotografías de los menores acompañados por ella, sin que hubiera mediado consentimiento alguno. Se hacen continuas alusiones a los hijos, cobrando así frente al lector un indudable

\footnotetext{
${ }^{25}$ SSAP de Madrid, 256/2011 de 23 de mayo y 557/2010 de 27 de diciembre.
} 
protagonismo. En la presente hipótesis no se discute la veracidad de la información, tampoco la notoriedad pública de la madre de los menores ni el hecho de que su imagen fuese captada simultáneamente con la de sus hijos en un lugar público. Sin embargo, estos planteamientos no pueden argüirse eficazmente para excluir la ilegitimidad de la intromisión y amparar la conducta del medio en el ámbito constitucionalmente protegido de su libertad de información, pues el suceso que plasma el reportaje carece de interés socialmente relevante (no puede serlo un suceso tan cotidiano y carente de interés general como el de ir de compras), y, aún admitiendo que tuviera interés para el público del sector social al que se dirige el medio ("prensa rosa" o "del corazón"), tampoco la notoriedad pública de la madre y el hecho de ser captada la imagen en lugar público podría justificar la publicación de la foto de los menores.

Hemos de concluir en este punto que en relación a éste tema no se podría ver reducida la protección del menor por el hecho de que en otras ocasiones estos menores hayan salido en medios de comunicación con el consentimiento de sus padres y justificar, en este sentido, su aparición accesoria. Indudablemente la accesoriedad debe apreciarse de modo restrictivo cuando se trata de la imagen de un menor de edad, ya que existe un interés superior en preservar su captación y difusión en los medios ${ }^{26}$. La interpretación que en este orden cabe hacer es la no aplicación de la doctrina de los actos propios, la cual nos llevaría a permitir que se pudieran captar imágenes de los menores en cualquier lugar y momento por el hecho de que se hayan consentido con anterioridad la publicación de imágenes de los mismos. Como bien dice la sentencia del Tribunal Supremo de 11 de marzo de 2009 "el consentimiento de los padres para la utilización de la imagen del menor ha de ser expreso, no deducido de actos previos, aunque incluso, como se dijo anteriormente, en supuestos de fotografías de menores, aun existiendo consentimiento, podría haber intromisión ilegítima".

\section{La teoría del reportaje neutral.}

Una vez tratados los conceptos de veracidad, interés público de la noticia, accesoriedad de la imagen en el ámbito de los menores, es consecuencia necesaria referirnos al denominado reportaje neutral como justificación de una noticia sobre

\footnotetext{
${ }^{26}$ CASTILLA BAREA, Margarita. Las Intromisiones Legítimas..., cit., pag. 375.
} 
menores para que no se produzca vulneración en los derechos que estamos tratando y se exima al medio que emita dicha información de cualquier tipo de responsabilidad.

El reportaje neutral, según la STS 15/2011, de 31 de enero, se aprecia cuando el medio de información se limita a divulgar los hechos relatados por un tercero, requiriendo para que tenga lugar, que se acredite la veracidad del hecho de las declaraciones del tercero, no de la certeza de esas declaraciones, y además que se refieran a hechos o circunstancias de relevancia pública. Se exige que sean por sí noticia y que el medio informativo solo las ponga en conocimiento de los ciudadanos sin alterar la importancia que tengan en el conjunto de la noticia ni reelaborarlas o provocarlas; en este caso la veracidad exigible se limita a la verdad objetiva de la existencia de la declaración. Este requisito resulta de menor trascendencia cuando se afecta al derecho a la intimidad personal y a la propia imagen.

El Tribunal Constitucional ha declarado que para que pueda hablarse de reportaje neutral han de concurrir los siguientes requisitos ${ }^{27}$ : a) el objeto de la noticia ha de hallarse constituido por declaraciones que imputan hechos lesivos del honor, pero que han de ser por sí mismas, esto es, como tales declaraciones, noticia y han de ponerse en boca de personas determinadas responsables de ellas, de manera que se excluye el reportaje neutral cuando no se determina quién hizo tales declaraciones; b) el medio informativo ha de ser mero transmisor de tales declaraciones, limitándose a narrarlas, como ya hemos dicho, sin alterar la importancia que tengan en el conjunto de la noticia, de tal forma que si se reelabora la noticia no existiría este tipo de reportaje. Cuando se reúnen ambas circunstancias la veracidad exigible se limita a la verdad objetiva de la existencia de dichas declaraciones y a la fidelidad a su contenido: si concurren las dos el medio ha de quedar exonerado de responsabilidad. En ningún caso se podrá manipular mediante su inclusión en uno de mayor extensión, interfiriendo en su discurrir con manifestaciones propias, componiéndolo con textos o imágenes cuyo propósito sea, precisamente, quebrar la neutralidad del medio de comunicación respecto de lo trascrito. De tal suerte que esa información si ha dejado de tener su fuente en un tercero, para hacerla suya el medio de comunicación que la reproduce y difunde habiendo permanecido o no ajeno a la generación de la información, se determinará la

\footnotetext{
${ }^{27}$ SSTC 54/2004, de 15 de abril, y 76/2002, de 8 de abril, STS 139/2007 de 4 de junio,
} 
calificación de este tipo de reportaje. Es o no información neutral, en base a la forma en que se ha transmitido al público ${ }^{28}$.

Buena parte de lo expuesto hasta el momento, y antes de plantear algunas cuestiones de necesaria valoración y reflexión, se recoge en la Sentencia del Juzgado de Primera Instancia núm.1 de Sevilla, de 11 de enero de 2011. Aquí el supuesto de hecho radica en la asistencia de una menor, de 14 años, con su madre a un programa de televisión para desmentir el rumor de que estuviese embarazada como consecuencia de su relación con un sujeto, el cual estaba imputado en la desaparición de otra menor. En todo momento aparece sin pixelar ni deformar su imagen. Podría justificarse, y así se intentó, su aparición en base a que la menor presenta unas condiciones de madurez suficientes y, además, la acompaña su madre como titular de la patria potestad. De manera que existe el consentimiento para la revelación de su imagen pública y podría ser de interés para ella misma y para la sociedad la aclaración de estas cuestiones, sin obviar que con anterioridad ya había hecho declaraciones en otros medios. Sin embargo el Ministerio Fiscal interpone demanda para la protección de sus derechos fundamentales, contra la cadena y las productoras, una de ellas alega en su defensa la teoría del reportaje neutral. Sin embargo, no se le informa de que su imagen puede no reconocerse ni del contenido de las preguntas que se le podrán realizar. A partir de estos datos se afirma en la sentencia que existe un menoscabo objetivo de su reputación y un perjuicio hacía sus intereses, ya que todo iba encaminado a aspectos sexuales que ella, en ningún caso, quería que trascendieran. En cuanto a la alegación de reportaje neutral

\footnotetext{
${ }^{28}$ En este sentido, no puede darse la teoría del reportaje neutral, según la STS 57/2012 de 13 de febrero, sobre entrevista en televisión a una persona conocida ya que, ni la productora, ni los periodistas que colaboran en el programa mantienen esa posición neutral , pues, de los comentarios transcritos de la entrevista efectuada a don Mateo , se deduce claramente que todo estaba preparado de antemano, que sabían de lo que este iba a hablar e, incluso, se le invitó al programa para ello. La propia representación del Sr. Mateo, afirma que fue el medio televisivo quien provoca la entrevista y la emisión de los comentarios atentatorios a la intimidad personal y familiar de la demandante. En la denominada información neutral solo se exige constatar la verdad del hecho de la declaración sin extenderse a la veracidad de esta, cuya constatación solo es exigible al autor de la declaración, sin embargo esta doctrina no es aplicable cuando se conoce que la información no es veraz, puesto que el reportaje neutral exige la ausencia de indicios racionales de falsedad evidente de lo trascrito, a fin de evitar que el reportaje neutro sirva indebidamente a la divulgación de simples rumores o insidias, pues resultaría absurdo que, con el pretexto de tratarse de reportaje neutral se pudiera difundir una información sobre la que existe constancia de que supone una intromisión ilegítima en el ámbito de protección de un derecho fundamental.
} 
se indica "que no cabe hablar de neutralidad cuando lo que está en juego es la protección de la intimidad y la imagen de una menor, cuyos intereses deben prevalecer sobre la curiosidad más o menos morbosa del público que pueda seguir los programas cuestionados, sobre el frívolo ejercicio de la profesión periodística y sobre la muy cuestionable actuación de la madre titular de la patria potestad, como primera persona llamada a velar por evitar que su hija fuera expuesta en la plaza pública virtual que es la televisión, con el objeto de desvelar aspectos de su vida íntima que sólo incumbían a ella y, a lo sumo, a su círculo de personas más próximas, de tal suerte que, como decimos, existe ese perjuicio objetivo”.

Sin embargo, en las hipótesis en las que están implicados menores de edad, la doctrina constitucional ha otorgado un ámbito de superprotección que obliga a ser sumamente cautelosos en cuanto a la información que de los mismos se suministra, aunque ésta tenga interés público. Y, así, el Tribunal Constitucional ha señalado que el legítimo interés de un menor de que no se divulguen datos relativos a su vida familiar o personal «parece imponer un límite infranqueable tanto a la libertad de expresión como al derecho fundamental a comunicar libremente información veraz, sin que la supuesta veracidad de lo revelado exonere al medio de comunicación de responsabilidad por la intromisión en la vida privada de ambos menores», incluso, aunque la noticia merezca el calificativo de información neutral ${ }^{29}$.

\section{CONSIDERACIONES FINALES}

De todo lo expuesto anteriormente, podemos afirmar que se ha avanzado en la protección de los menores en general y en su relación con los medios de comunicación, en particular. La normativa actual en la materia, como todo mejorable, protege con cierta eficacia los derechos de los menores afectados. Cuando colisionan aquellos con los propios, también respetables y a proteger, del derecho a la información en el inevitable juicio de ponderación, al que extensamente se ha aludido en epígrafes anteriores, se aprecia una clara tendencia, no totalmente pacífica, a la estimación preeminente a la protección relevante del derecho al honor, a la intimidad y a la propia imagen del menor, lo que no sucede en relación con los adultos donde el equilibrio

\footnotetext{
${ }^{29}$ STC134/1999 de 15 de julio. PAÑOS PÉREZ, Alba. El interés del menor como criterio para determinar la ilegitimidad...,cit., pág . 9.
} 
cuantitativo en las decisiones está más equilibrado cuando no volcado hacia los derechos informativos, según los casos.

La especial garantía con la que cuentan los menores, deriva de su madurez y del consentimiento prestado por ellos o por sus representantes legales. Desde nuestro punto de vista y tal cual es la realidad social en esta materia, es imprescindible y muy importante la actuación del Ministerio Fiscal, cuando son los propios familiares o peor todavía los propios padres los que consienten la intromisión ilegítima, acompañando a los menores a un plató de televisión, o relatando ellos mismos el hecho en cuestión de forma que fácilmente se les pueda reconocer.

Consideramos igualmente que existe un problema de origen o insuficiencia legislativos, en la protección del derecho a la intimidad, al honor y a la propia imagen, sabiendo en términos de responsabilidad civil, que obviamente como cualquier daño que se produce, ha de tener existencia para que se pueda reparar, con la peculiaridad que siempre será un daño moral, que por afectar a intereses extrapatrimoniales, será difícil de cuantificar. En este contexto si creemos factible que se pueda evitar. Lo que es difícil de comprender, a pesar de todo, es la excesiva y, a veces sorprendente permisividad con la que cuentan determinadas cadenas de televisión o periódicos que emiten noticias sobre menores sabiendo, a priori que se está atentando contra sus derechos.

Brevemente señalar, en este sentido y en clave de conclusión, dos casos juzgados en el Tribunal Supremo ${ }^{30}$. En el primero de ellos dos abuelas acuden a la televisión a narrar todo lo referente a la tutela de sus nietos, incluyendo que la madre de uno no quería saber nada, que los padres del otro eran drogodependientes, y otras circunstancias que afectan a su intimidad. En el programa se emiten imágenes de los mismos, para que fueran claramente identificados y para que cualquiera que los viera informare sobre su paradero. Ni los menores, ni sus representantes legales habían prestado su consentimiento para la difusión de la noticia ni las imágenes. De cualquier manera, al referirse al derecho a la intimidad y a la propia imagen no basta con el consentimiento tácito de sus representantes pues éste ha de otorgarse por escrito y comunicado al Ministerio Fiscal.

\footnotetext{
${ }^{30}$ SSTS 485/2010 de 26 de julio y 354/2011 de 31 de mayo.
} 
El segundo versa sobre la participación de una madre en un periódico local que publica una serie de artículos relativos al conflicto sobre la guarda y custodia de la hija que se había atribuido judicialmente al padre. A quien había acusado de abusos sexuales hacia la hija, situación que la Audiencia había acabado archivando. El diario publicaba las denuncias contra el padre y los partes médicos de los que se sospechaba la existencia de tales abusos.

En ambos casos es el Fiscal el que interponen sendas demandas. En el primero por intromisión en la intimidad de los menores; en el segundo por lesión del derecho a la intimidad de la menor. En los dos, los perjuicios morales que los menores sufren debido al conocimiento público y la difusión de su situación familiar, han de ser a priori evitados. No se duda de la veracidad de la noticia, del interés social que pueda tener, pero no es tolerable, en ningún caso, que la mayor o menor desgracia de un menor sea conocida a nivel nacional o local.

Es obvio, por otra parte, que las historias se pueden contar y escribir, que en muchos casos tendrán interés público, que el familiar mayor de edad y con plena capacidad participe en tantos programas como desee, poniendo a disposición del espectador su imagen, o bien a través de algún comunicado a los medios, del hecho que suscite el interés. Pero asimismo lo es, sobre la normativa vigente, anteriormente analizada, que cuando ello afecte a menores de edad se ha de hacer con suma cautela y, en todo caso, con absoluto respeto a sus derechos e intereses y al más hermético anonimato de su persona. No eximiendo de ello, sino todo lo contrario, a los menores de hijos de famosos que de igual manera, como tales menores, han de tener la misma protección y respeto a sus derechos básicos. 
